GRASAS Y ACEITES 68 (4)

October-December 2017, e225

ISSN-L: 0017-3495

doi: http://dx.doi.org/10.3989/gya.0775171

\title{
Chemical composition and resistance to oxidation of high-oleic rapeseed oil pressed from microwave pre-treated intact and de-hulled seeds
}

\author{
A. Rękas ${ }^{\mathrm{a}, \bowtie}$, M. Wroniak ${ }^{\mathrm{a}}$, A. Siger ${ }^{\mathrm{b}}$ and I. Ścibisz ${ }^{\mathrm{a}}$ \\ ${ }^{a}$ Faculty of Food Sciences, Department of Food Technology, Warsaw University of Life Sciences, Nowoursynowska St. 159c, 02-787 \\ Warsaw, Poland \\ ${ }^{b}$ Faculty of Food Sciences and Nutrition, Department of Food Biochemistry and Analysis, Poznań University of Life Sciences, \\ Wojska Polskiego St. 28, 60-637 Poznań, Poland \\ ${ }^{凶}$ Corresponding author: agnieszka_rekas@sggw.pl
}

Submitted: 02 July 2017; Accepted: 26 September 2017

SUMMARY: The influence of a microwave (MV) pre-treatment $(3,6,9 \mathrm{~min}, 800 \mathrm{~W})$ on the physicochemical properties of high-oleic rapeseed oil prepared from intact (HORO) and de-hulled seeds (DHORO) was investigated in this study. A control DHORO contained higher levels of total tocopherols and carotenoids, while higher concentrations of total phenolic compounds and chlorophylls were detected in the HORO. The MV pre-treatment caused a decrease in the unsaturated fatty acids content that was more evident for the DHOROs. The microwaving time significantly affected phytochemical contents and the color of both types of oils. A vast increase in canolol concentration was noticeable following 9 min of microwaving, which increased 506- and 155-fold in the HORO and DHORO, respectively. At the same time, the antioxidant capacity of oil produced from MV pre-treated seeds for 9 min was nearly 4 times higher than that of the control oil for both types of oils.

KEYWORDS: Fatty acids; High-oleic rapeseed oil; Hulling; Microwaving; Oxidative stability; Phytochemicals

RESUMEN: Composición química y resistencia a la oxidación de aceite de colza alto oleico prensado de semillas intactas y descascarilladas pre-tratadas con microondas. En este estudio se investigó la influencia del pretratamiento con microondas (MV) en las propiedades fisicoquímicas del aceite de colza alto oleico preparado a partir de semillas húmedas (HORO) y descascarilladas (DHORO) (3, 6, 9 min, 800W). El control DHORO contenía un nivel más alto de tocoferoles totales y carotenoides, mientras que se detectó una mayor concentración de compuestos fenólicos totales y clorofilas en el HORO. El pretratamiento de MV provocó una disminución en el contenido de ácidos grasos insaturados que fue más evidente para los DHOROs. El tiempo de microondas afectó significativamente al contenido fitoquímico y al color de ambos tipos de aceites. Se observó un gran aumento de la concentración de canolol después de 9 min de microondas, que aumentó 506 y 155 veces en el HORO y DHORO, respectivamente. Al mismo tiempo, la capacidad antioxidante del aceite producido a partir de semillas pretratadas de MV durante 9 min fue casi 4 veces mayor que la del aceite de control para ambos tipos de aceites.

PALABRAS CLAVE: Aceite de colza alto oleico; Ácidos grasos; Descascarillar; Estabilidad oxidativa; Fitoquimicos; Microondas

ORCID ID: Rękas A http://orcid.org/0000-0001-5979-8430, Siger A http://orcid.org/0000-0002-3681-153X, Wroniak M http://orcid.org/0000-0002-8527-7185, Ścibisz I http://orcid.org/0000-0003-1291-8962

Citation/Cómo citar este artículo: Rękas A, Siger A, Wroniak M, Ścibisz I. 2017. Chemical composition and resistance to oxidation of high-oleic rapeseed oil pressed from microwave pre-treated intact and de-hulled seeds. 2107. Grasas Aceites 68 (4), e225. http://dx.doi.org/10.3989/gya.0775171

Copyright: (C2017 CSIC. This is an open-access article distributed under the terms of the Creative Commons Attribution (CC-by) Spain 3.0 License. 


\section{INTRODUCTION}

Rapeseed/canola now occupies the third position in rank order for the production of oils and fats after palm and soybean oil. EU-27, China and India dominate the production and consumption of this oil, whereas Canada is an important grower and exporter of rapeseeds (FAOSTAT, 2017). In the early 1960's Canadian plant breeders isolated rapeseeds with low eicosenoic and erucic acid contents. As a result, the past 50 years have seen significant growth in rapeseed production due to the introduction of rapeseed (canola) which is low in erucic acid (C22:1) and glucosinolates. Since then, rapeseed regained status in the market as a healthy vegetable oil. The term "rapeseed oil" is used for the original (erucic acid free) variety with around 10\% linolenic acid. Presently, the fatty acid profile of rapeseed oil has been modified according to its health benefits, such as low linoleic acids (LLi), or to enhance nutritional and functional quality by introducing high-oleic acid (HOAR) or high-oleic/low linolenic acid (HOLLi) rapeseed varieties into the market. Rapeseed oil which contains more than $60 \%$ erucic acid (HEAR) has regained interest for biodegradable plastic, cosmetic, emollient industries and for biodiesel (Nath et al., 2016).

The studies investigating the effect of low-erucic rapeseed (LEAR, canola) hulling are few and contradictory. Wroniak et al. (2013) found that conditioning rapeseed hulling decreased the amount of tocopherols and unsaturated fatty acids in the oil, while the effect of hulling on the oxidative stability of the oil was observed. Yang et al. (2011) reported that rapeseed hulling decreased the amount of tocopherols and sterols in the oil, but paradoxically increased the oxidative stability of the oil, as shown by a higher induction period in the Rancimat test. An unfavorable effect of hulling on the oxidative stability of the oil has also been demonstrated after the de-hulling of sesame seeds (Abou-Gharbia et al., 1997).

The effect of soybean and sunflower seed microwave pre-treatment on the bioactive compound contents, oxidative stability and color change in the oil has been well documented (Anjum et al., 2006; Yoshida et al., 1999). The microwave pre-treatment of rapeseeds has been restricted to emphasize its impact on the phytochemical contents and oxidative stability Azadmard-Damirchi et al., 2010, Yang et al., 2013) or flavor characteristics (Zhou et al., 2013).

This study was performed to provide information on the effect of hulling of high-oleic rapeseed on the physicochemical properties of the oil. De-hulling can improve the color, flavor and nutritional value of the oil, and therefore, the phytochemical contents and oil color change following rapeseed hulling were determined. Since high-oleic rapeseed oils are recommended for processes where high stability of the oil is required such as deep-fat frying, this work focused on the impact of the intact and de-hulled seeds' thermal pre-treatment by microwave on the extent of the oil's oxidation, measured by quantitative changes in fatty acid content, formation of primary and secondary oxidation products and the oxidative stability.

Therefore, the aims of this study were to (1) investigate the effect of hulling on the physicochemical composition of the resulting oil; (2) investigate the oxidative resistance to oxidation of the oil pressed from high-oleic rapeseeds.

\section{MATERIALS AND METHODS}

\subsection{Experimental material}

Seeds of high-oleic rapeseed were provided by the Złoto Polskie CLP (Kalisz, Poland). Seeds were harvested at optimum maturity, and did not contain any impurities or broken seeds. The moisture content of the rapeseeds was $6.1 \%$.

\subsection{Reagents}

Analytical standards of tocopherols (> 95\%), HPLC-grade n-hexane, methanol, acetonitrile $(\mathrm{ACN})$, orthophosphoric acid, and 1,4-dioxane were provided by Calbiochem-Merck Biosciences (Darmstadt, Germany). KOH in methanol (1M), hexane, sodium methoxide $(0.4 \mathrm{~N}), 2$,2-diphenyl1-picrylhydrazyl radical (DPPH) and ( \pm )-6-hydroxy2,5,7,8-tetramethylchroman-2-carboxylic acid (Trolox), were purchased from Sigma-Aldrich (St. Louis, MO, USA). All other solvents and chemicals used in this study were of analytical grade.

\subsection{Sample moisturizing}

The moisture content of the seeds was determined based on a precision weighing balance, using an Electronic Moisture Analyzer (Kern \& Sohn $\mathrm{GmbH}$, Germany). The seeds (batches of $500 \mathrm{~g}$ ) were sprayed with a pre-calculated amount of water, mixed thoroughly, sealed in polyethylene bags and equilibrated at $4 \pm 2{ }^{\circ} \mathrm{C}$ for $72 \mathrm{~h}$. Based on the results presented in our previous work (Rękas et al., 2017a) a seed moisture level of $7.5 \%$ prevents seeds from overheating during microwave pre-treatment, whereas seed moisturizing prior to cold-pressing to the moisture content of $8.5 \%$ enables the highest oil yield. For this reason, the seeds were moistened twice: to the moisture content of $7.5 \%$ prior to microwave pre-treatment and before cold-pressing to reach the required moisture content of $8.5 \%$. After $72 \mathrm{~h}$ of equilibration, the moisture content of the seeds was checked in order to verify whether homogeneous moisture distribution throughout the bulk of the seeds was reached. 


\subsection{Mechanical de-hulling}

Mechanical hulling of the rapeseeds was performed using a shearing disc sheller equipped with cylindrical blades, developed by Anders (2003) following the method described in our previous work (Rękas et al., 2017b).

\subsection{Pre-treatment with microwaves}

For each microwave (MV) pre-treatment, $500 \mathrm{~g}$ of seeds were placed in a glass beaker (16-cm diameter) inside the microwave (Model: NN-J155W). The seeds were exposed to microwave irradiation for 3, 6, and 9 min $(2450 \mathrm{MHz}, 800 \mathrm{~W})$. Intact and dehulled high-oleic rapeseed samples without microwave radiation ( 0 min radiation time) were used a control sample. Each experiment was performed in triplicate for all variants of the microwave radiation. Following each heating run, seeds were allowed to cool to ambient temperature and thoroughly mixed to obtain a homogenous sampling.

\subsection{Cold-pressing}

Pressing was carried out by applying the screw press method (Farmet, Czech Republic), where the temperature was kept below $40^{\circ} \mathrm{C}$. Once produced, the oil was stored at $4{ }^{\circ} \mathrm{C}$ overnight in the dark until analyzed.

\subsection{HPLC analysis of tocopherols, plastochromanol-8 and canolol}

Tocochromanols $(\alpha-, \beta-, \gamma$-, and $\delta$-tocopherol and plastochromanol-8) and canolol were determined according to the method described by Siger et al. (2015). In brief, a $200 \mathrm{mg}$ oil sample was dissolved in $10 \mathrm{ml}$ of $\mathrm{n}$-hexane and transferred to vials for further analysis. Separation was performed using a Waters HPLC system (Waters, Milford, MA, USA) coupled with a FLD detector (Waters 474), a PDA detector (Waters 2998), and a LiChrosorb Si-60 column $(250 \times 4.6 \mathrm{~mm}, 5 \mu \mathrm{m}$, Merck Millipore, Darmstadt, Germany). The mobile phase was a mixture of $\mathrm{n}$-hexane with 1,4-dioxane $(96: 4 \mathrm{v} / \mathrm{v})$ with a flow rate $1.0 \mathrm{ml} \mathrm{min}^{-1}$ (for tocopherols and plastochromanol-8) and $2.0 \mathrm{~min}^{-1}$ (for canolol). Quantification of tocochromanols and canolol was conducted using data from the FLD with excitation/ emission wavelengths of $295 / 330 \mathrm{~nm}$ and $280 / 325 \mathrm{~nm}$, respectively. The plastochromanol- 8 contents were assayed and calculated following the method described by Siger et al. (2014).

\subsection{Analysis of total phenolic compounds}

The total phenolic content was determined by the Folin-Ciocalteau colorimetric method (Koski et al., 2002). Sinapic acid was used for calibration, and the results were expressed as milligram of sinapic acid per $100 \mathrm{~g}$ oil.

\subsection{Identification and quantification of fatty acid methyl esters by GC-FID}

Fatty acid methyl esters (FAMEs) were prepared using sodium methoxide $\left(\mathrm{CH}_{3} \mathrm{ONa}, 0.4 \mathrm{~N}\right)$ as a catalyst, following the method described previously (Rękas et al., 2017b). The fatty acids were identified using a reference mixture of fatty acids methyl esters (FAME). Nonadecanoid acid (C19:0) was used as internal standard for the quantification.

\subsection{Color indices}

The total chlorophyll content $(\mathrm{mg} / \mathrm{kg}$ ) was quantified by spectrophotometry according to the AOCS Method (1997). The total carotenoid content was measured according to the BSI Method (1977).

The non-enzymatic browning index was assayed spectrophotometrically for oil samples diluted in chloroform at $420 \mathrm{~nm}$ (Yoshida et al., 1999).

The CIE Lab coordinates ( $\left.\mathrm{L}^{*}, \mathrm{a}^{*}, \mathrm{~b}^{*}\right)$ were directly read with a spectrophotometer (CM-3600d, Konica Minolta, Japan). Color difference $(\Delta \mathrm{E})$ was calculated as $\Delta \mathrm{E}=\left[\left(\mathrm{L}_{0} *-\mathrm{L}^{*}\right)^{2}+\left(\mathrm{a}_{0} *\right.\right.$ $\left.\left.\mathrm{a}^{*}\right)^{2}+\left(\mathrm{b}_{0}{ }^{*}-\mathrm{b}^{*}\right)^{2}\right]^{1 / 2}$, where $\mathrm{L}_{0} *, \mathrm{a}_{0}{ }^{*}$, and $\mathrm{b}_{0}{ }^{*}$ are the color parameters of the control HORO and DHORO.

\subsection{Oil oxidation indices}

The peroxide value (PV), p-anisidine value (p-AnV), and K232 and K268 extinction coefficients, were measured following ISO standard methods (3960:2005; 6885:2008; 3656:2011).

Oxidative stability, expressed as the oxidation induction period (hours), was measured with the Rancimat apparatus (model 743 Metrohm Co, Herisau, Switzerland) using an oil sample of $2.5 \mathrm{~g}$ warmed to $120{ }^{\circ} \mathrm{C}$, and an air flow of $20 \mathrm{l} / \mathrm{h}$. All determinations were carried out in triplicate.

\subsection{Antioxidant capacity}

The radical scavenging capacity (RSC) of the oil sample was analyzed using the DPPH radical-scavenging following the method described by Tuberoso et al. (2007). The antioxidant capacities of the oil (TF), hydrophilic (HF), lipophilic (LF) fraction were measured spectrophotometrically at $517 \mathrm{~nm}$ (Spectronic Helios $\beta$ UV-Vis, Thermo Electron Corporation, Waltham, MA, USA). The results were expressed as a Trolox equivalent antioxidant capacity (TEAC, $\mathrm{mmol} \mathrm{l}^{-1}$ ), using a Trolox calibration curve in the range of $0.02-4.00 \mathrm{mM}$. 


\subsection{Statistical analysis}

A statistical analysis was carried out with Statistica v. 12 software (StatSoft, Inc., Tulsa, OK, USA). Statistical differences among the oil samples were estimated by applying one-way ANOVA and using the Tukey test at a significance level of $\mathrm{p}<0.05$.

\section{RESULTS AND DISCUSSION}

\subsection{The effect of microwave pre-treatment on the phytochemical contents}

The contents of the individual tocopherol homologues in the HOROs and DHOROs prepared at the different MV conditions, as well as in the coldpressed oil, are given in Table 1. A total of 4 tocopherol homologues $(\alpha, \beta, \gamma$ and $\delta$ ) were identified in the rapeseed oil, which is consistent with previous studies (Yang et al., 2013; Siger et al., 2015). The total tocopherol contents in the control HORO and

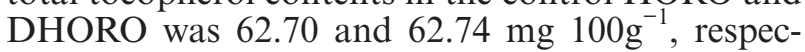
tively, with the preponderance of $\gamma$-tocopherol (more than $58 \%$ of total tocopherols). The plastochromanol-8 (PC-8) content in the control DHORO was $2.78 \mathrm{mg}^{100 \mathrm{~g}^{-1}}$ and was slightly higher than in the control HORO $\left(2.49 \mathrm{mg} 100 \mathrm{~g}^{-1}\right)$. The favorable of effect low-erucic rapeseed on the tocopherol concentrations in the oil was demonstrated by the results obtained by Yang et al. (2011) and Wroniak et al. (2013).

Since tocopherols are thermal-sensitive, it was expected that the oil from MV seeds would have lower tocopherol concentrations. However, as the seeds' MV pre-treatment time increased, the total tocopherol content of the oil increased. A maximum total tocopherol concentration in the oil was achieved following $9 \mathrm{~min}$ of seed microwaving, where 70.03 and $71.19 \mathrm{mg} \cdot 100 \mathrm{~g}^{-1}$ of total tocopherols were determined in the HORO and DHORO, respectively. However, $\alpha-$ and $\beta-T$ were found to decrease with longer seed exposure to MV. At the same time, an increase in $\gamma$ - and $\delta$-T was noticed (Table 1). Moreover, the HOROs' tocopherols were more susceptible to degradation during seed MV than the DHOROs. After 9 min of MV, the levels of $\alpha$-T were reduced to $24.7 \mathrm{mg} \cdot 100 \mathrm{~g}^{-1}(3.4 \%)$ and $25.10 \mathrm{mg} \cdot 100 \mathrm{~g}^{-1}(0.8 \%)$, for HORO and DHORO, respectively. The respective increase in $\gamma$-T was $44.60 \mathrm{mg} \cdot 100 \mathrm{~g}^{-1}(22.4 \%)$ and $45.37 \mathrm{mg} \cdot 100 \mathrm{~g}^{-1}(24 \%)$. After 6 min of MV, a 2-fold increase in PC-8 was noted, whereas extending $\mathrm{MV}$ time to $9 \mathrm{~min}$ did not cause a significant increase in this compound concentration in the HORO or DHORO. A reduction in $\alpha$-T after seed and nut MV was observed by other authors (Yoshida et al., 1999; Anjum et al., 2006; Cai et al., 2013). The roasting of rapeseeds
(Siger et al., 2015) and pumpkin seeds (Vujasinovic et al., 2012) was found to increase $\gamma$-T concentration in the oil, while the roasting of pine nuts (Cai et al., 2013) and sunflower seeds (Anjum et al., 2006) resulted in a reduction in this compound. As shown by Moreau et al. (1999) a significant amount of $\gamma$-T in corn hulls formed complexes with proteins or was linked to phosphates or phospholipids. An increase in $\gamma$ - $T$ in the oil may be a result of heat-induced degradation of these bonds. Wijesundera et al. (2008) offered a possible explanation for the heat-induced increase in the levels of tocopherols, suggesting a possible co-elution of tocopherols with other compounds formed during rapeseed roasting. Although browning substances, resulting from Maillard-type reactions, are very polar due to active radicals, as suggested by McDaniel et al. (2012) it is possible that some Maillard browning compounds are oil soluble. This would partially explain the potential role of Maillard browning products in protecting the tocopherols from degradation.

Although the levels of total phenolics and canolol were higher in the control DHORO (0.41 and $0.76 \mathrm{mg} 100 \mathrm{~g}^{-1}$, respectively), with a longer seed exposure to MV, a greater increase in these compound concentrations was found in the HOROs (Table 2). After 6 and 9 min of MV of de-hulled seeds, the levels of canolol were 9- and 155-fold higher in DHORO than in the control DHORO. Intact seeds' MV for 6 and 9 min resulted in a 30and 506-fold increase in canolol concentrations in the HOROs. A vast increase in canolol contents in the oil pressed from microwaved/roasted seeds was also reported by other authors (Yang et al., 2014; Siger et al., 2015). An increase in total phenolic compounds in the oil was also found for nut and oilseed roasting, although the changes in total phenolics in the oils were dependent on the roasting temperature and processing time (Vujasinovic et al., 2012; Cai et al., 2013). Generally, oilseed thermal pretreatment causes evaporation of intracellular water, triggering chemical reactions that can change the lignocellulosic structure and promote protein denaturation, which may result in a greater availability of plant phenolic compounds in the matrix. This phenomenon was confirmed in a study by Yang et al. (2014) where MV pre-treatment applied to rapeseed yielded increased transfer of phenolic compounds from rapeseed to oil.

\subsection{The effect of microwave pre-treatment on color changes in the oil}

Chlorophyll and carotenoids, together with membrane proteins and membrane lipids, form a membrane-bound compartment called thylakoid. Crude rapeseed oil may contain as much as $95 \mathrm{mg} \mathrm{kg}^{-1}$ total carotenoids. Unlike carotenoids, chlorophyll and its derivative (pheophytin) are not wanted in oils 
Chemical composition and resistance to oxidation of high-oleic rapeseed oil pressed $\bullet 5$
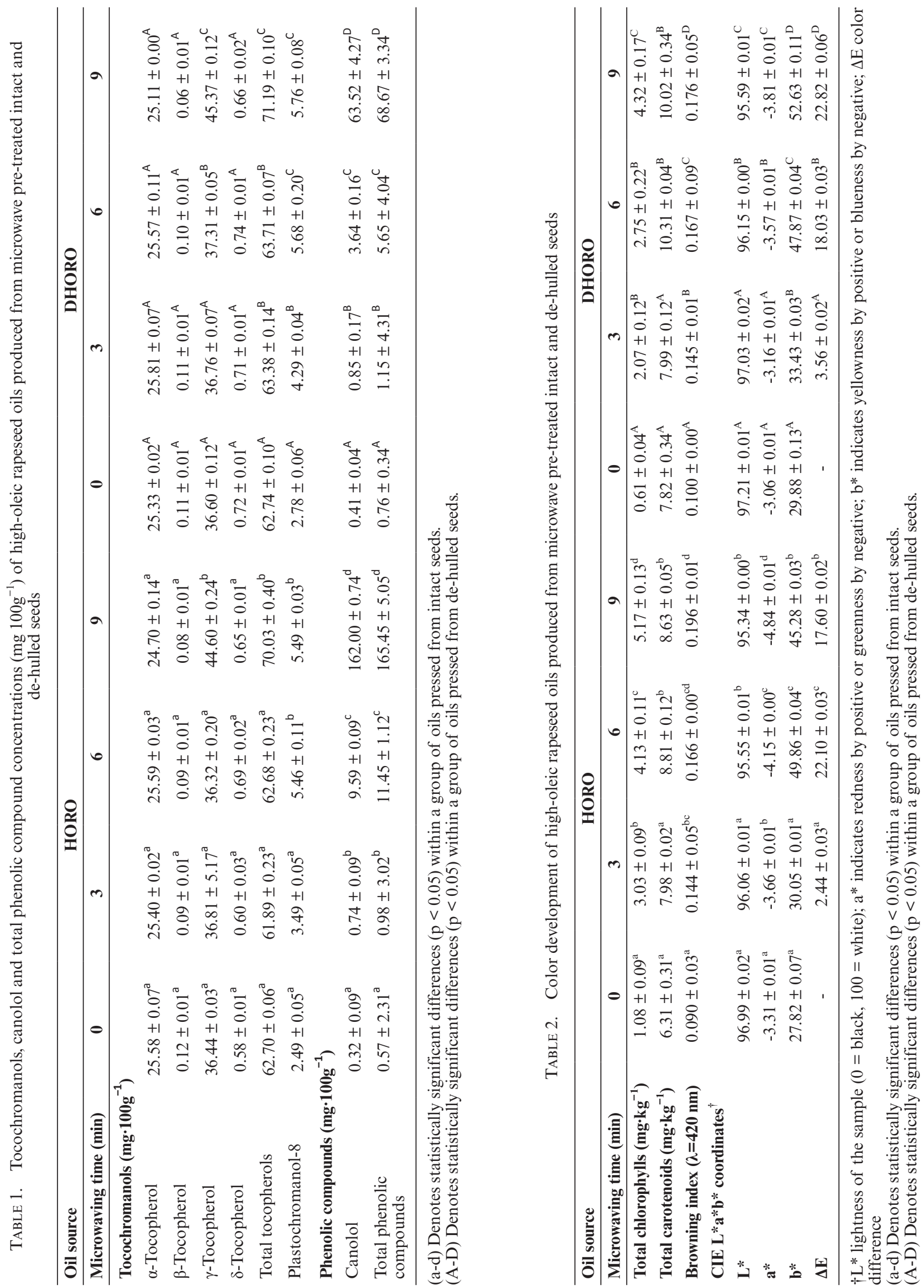
because they produce an undesirable green hue in the oil, in addition to the pro-oxidative effect of chlorophylls in oil exposed to light. The level of chlorophylls in the crude rapeseed oil may vary from 5 to 25 ppm (Przybylski, 2011). In our study, the control oils contained very low amounts of chlorophylls; however, the level of chlorophyll pigments in the DHORO was nearly 2-times lower $\left(0.61 \mathrm{mg} \mathrm{kg}^{-1}\right)$ than in the control HORO $\left(1.08 \mathrm{mg} \mathrm{kg}^{-1}\right)$. Extending the time of seeds' MV yielded a significant $(\mathrm{p}<0.05)$ increase in the total carotenoid and chlorophyll contents (Table 2).

A color change in the oil was the most noticeable effect of rapeseed de-hulling. The DHORO had a bright yellowish color, suggesting that the coloring compounds, especially those responsible for the undesirable green hue, were significantly removed from the seeds by de-hulling (Abou-Gharbia et al., 1997). By increasing MV time, an increase in the browning index and a distinct color change $(\Delta \mathrm{E})$ was noted (Table 2). Although higher browning index values were noted for the HOROs, the MV of de-hulled seeds resulted in a more noticeable oil color change, as indicated by the calculated color difference $(\Delta \mathrm{E})$. However, in both types of oils, intensification of the brown color increased with longer seed MV pre-treatment. Gradual oil darkening and higher CIE $\mathrm{L}^{*} \mathrm{a} * \mathrm{~b} *$ indices with increasing roasting/microwaving time of oilseeds and nuts was reported by other authors (Megahed, 2001; Anjum et al., 2006; Cai et al., 2013). According to those authors, color intensity increases with the formation of browning substances, as a result of Maillardtype non-enzymatic reactions and phospholipid degradation.

\subsection{The effect of microwave pre-treatment on oxidative stability}

High oleic rapeseed oil combines high oxidation stability with the lowest saturated fatty acid contents among other commercial edible oils (Merrill et al., 2008). The fatty acid content (mg $\left.100 \mathrm{~g}^{-1}\right)$ of both the control HORO and DHORO was typical for the high-oleic rapeseed - the dominant fatty acid was $\mathrm{C} 18: 1$, followed by $\mathrm{C} 18: 2$ and $\mathrm{C} 18: 3$, in the concentrations of $76.58,76.32 ; 10.65,10.86 ; 4.80$, $4.93 \mathrm{mg} \cdot 100 \mathrm{~g}^{-1}$, respectively (data not shown).

The de-hulling of rapeseed prior to microwaving affected fatty acids' susceptibility to thermal degradation (Figure 1). After 6 min of MV, the percentage loss in PUFAs was 5.6 and $8.3 \%$, for the HORO and DHORO, respectively. Seed MV for $9 \mathrm{~min}$ caused the highest degradation of PUFAs, where 11.9 and $14.5 \%$ of PUFAs had degraded, respectively. MV pre-treatment of the intact and de-hulled seeds was found to affect MUFA and SFA contents. After 9 min of MV, the amount of SFAs decreased from 6.63 to $6.53 \mathrm{mg} \cdot 100 \mathrm{~g}^{-1}$ for HORO, and from 6.65 to $6.51 \mathrm{mg} \cdot 100 \mathrm{~g}^{-1}$, for DHORO. The respective loss in MUFAs was within the range of 77.89-72.31 $\mathrm{mg} \cdot 100 \mathrm{~g}^{-1}$ and $77.92-70.95 \mathrm{mg} 100 \mathrm{~g}^{-1}$. As shown by Gracka et al. (2016), the loss in SFAs, MUFAs and PUFAs after roasting of low-erucic rapeseed was nearly 2-fold lower when compare to the fatty acid loss in the oil pressed from high-oleic rapeseed oil.

As shown in Table 3, the initial oxidative quality of the control DHORO was comparable to that of the control DHORO. After microwaving, the HOROs were more stable than the DHOROs, as reflected in $\mathrm{PV}, p-\mathrm{AV}$ and the values of conjugated

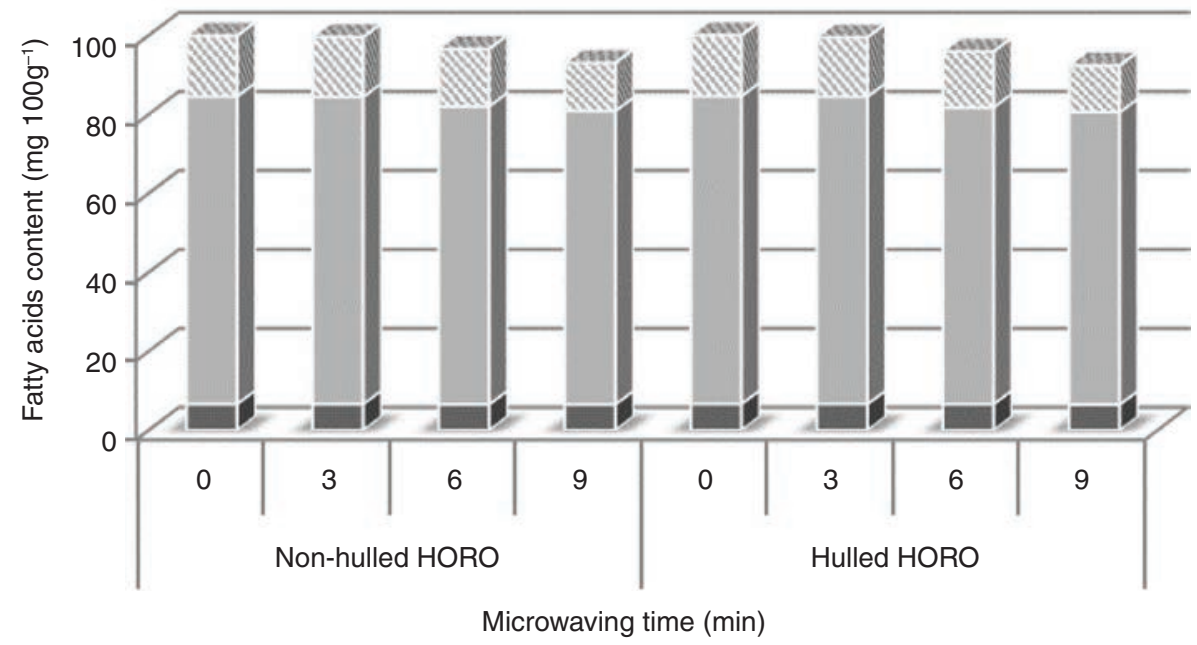

Figure 1. The effect of microwave pre-treatment on the changes in fatty acid contents $\left(\mathrm{mg} 100 \mathrm{~g}^{-1}\right)$ of high-oleic rapeseed oils. 


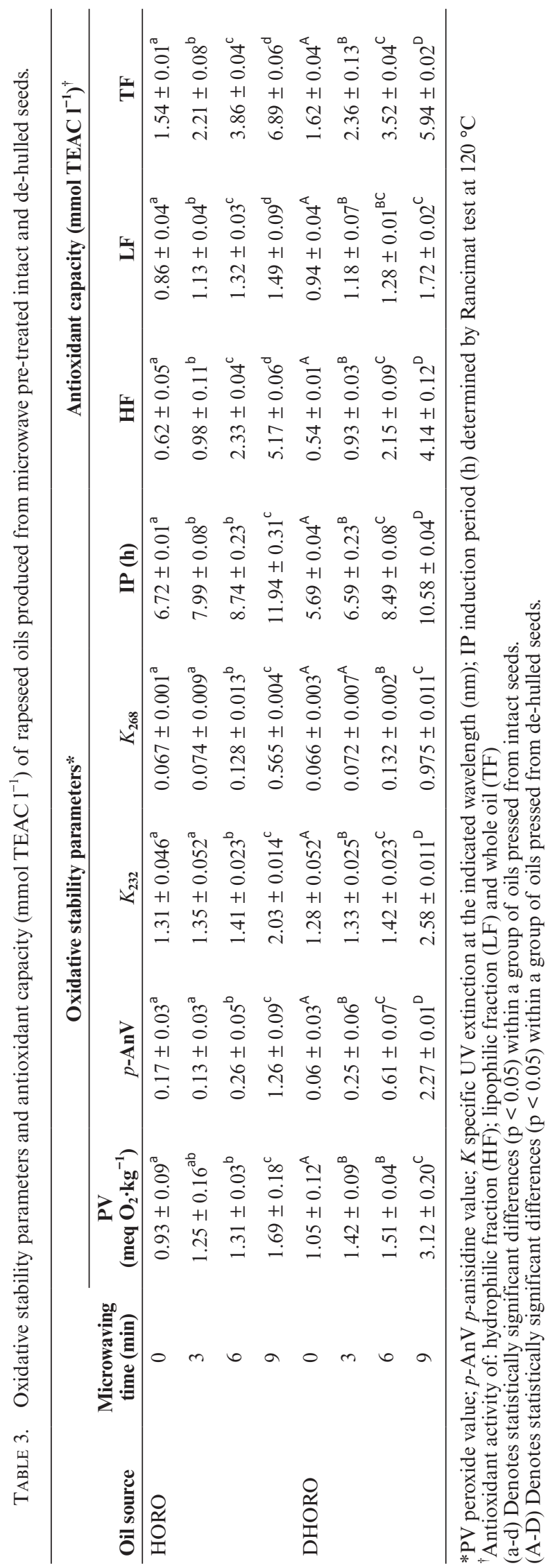

dienes and trienes. Abou-Gharbia et al. (1997) found that oils from coated sesame seeds were more resistant to oxidation than those extracted from de-hulled seeds after roasting and microwaving. The results of the Rancimat test showed that hulling decreased the oxidative stability of the oil, as the induction period (IP) determined for the control HORO was higher $(6.72 \mathrm{~h})$ than that of the control DHORO $(5.69 \mathrm{~h})$. By extending MV time, a gradual increase in IP was observed, which is in agreement with studies employing rapeseed MV pre-treatment (Azadmard-Damirchi et al., 2010; Yang et al., 2013). The oxidative stability of the HOROs and DHOROs showed 2-fold higher IP after seeds' 9 min exposure to microwaves when compare to the control oil, and were 11.94 and $10.58 \mathrm{~h}$, respectively. This special phenomenon of a vast increase of the oils' oxidative stability was also observed after different oilseed thermal pretreatments (Wijesundera et al., 2008; Vaidya and Choe, 2011; Vujasinovic et al., 2012).

\subsection{The effect of microwave pre-treatment on antioxidant capacity}

The antioxidant capacity of the methanol soluble phase (HF) was higher for the control HORO, while a higher TEAC value of the insoluble in methanol fraction (LF) was calculated for the control DHORO (Table 3). On the whole (TF), the control DHORO showed a higher TEAC value $\left(1.62 \mathrm{mmol} \cdot 1^{-1}\right)$ than the control HORO $\left(1.54 \mathrm{mmol} \cdot \mathrm{l}^{-1}\right)$. As MV time increased from 3 to $9 \mathrm{~min}$, the TEAC values of TF increased from 2.21 to $6.89 \mathrm{mmol} \cdot \mathrm{l}^{-1}$, for the HORO, and from 2.36 to $5.94 \mathrm{mmol} \cdot \mathrm{l}^{-1}$, for the DHORO.

In general, the rapeseed oil lipophilic fraction contains mainly tocopherols, carotenoids and phospholipids, whereas phenolic compounds are the major constituents of the hydrophilic fraction. The relative antioxidant activity in vitro of tocochromanol homologues varies greatly due to its dependence on a number of factors, including the composition of the system, the temperature, the structure of the lipid phase, and the concentration of tocochromanols (Falk and Munné-Bosch, 2010). Because of the complex interplay between the chemical and physical parameters of the lipid substrate and of the overall system, the order of antioxidant activity of tocochromanol homologues resulting from the balance between anti- and pro-oxidant activates, as well as the prediction of antioxidant activity of tocochromanols, is unreliable. As shown by Kamal-Eldin (2006), the pro-oxidant or antioxidant activity intimately depends on their concentration. The inhibition of vegetable oil oxidation is usually associated with a critical minimal concentration of antioxidants $\left(60-70 \mathrm{mg} \cdot \mathrm{kg}^{-1}\right.$ of a tocopherol in olive oil). (Blekas et al., 1995). Studies by Goffman et al. (1999) revealed that the tocopherol contents in 
oils (Brassicaceae family) are close to their optimal amounts needed for the stabilization of these oils.

The antioxidant activity of phenolic acids and their esters depends on the number of hydroxyl groups in the molecule. Monophenols are less efficient antioxidants than polyphenols, the presence of a secondary hydroxyl group in the ortho or para position increases the antioxidant activity of hydroxylated phenolic acids; however, the presence of more than three hydroxyl groups in a given aromatic nucleus does not improve the antioxidant efficacy (Shukla et al., 1997). The presence of a $\mathrm{CH}=\mathrm{CH}-\mathrm{COOH}$ group in cinnamic acids (caffeic, $p$-coumaric, ferulic, sinapic acids) ensures greater efficiency of antioxidative ability than the $\mathrm{COOH}$ group in benzoic acids (protocatechuic, $p$-hydroxybenzoic, vanillic, syringic acids); however, a single $\mathrm{COOH}$ group exhibits a negative role in antioxidative activity (Cuvelier et al., 1992).

The heat pre-treatment of oilseeds leads to the formation of new antioxidants, including canolol and Maillard reaction products. Canolol (2,6-dimethoxy4-vinylphenol) classified as phenolic compound has gained interest in recent years due to antioxidant, anticancer, anti-inflammatory, and antibacterial activities. There are a number of scientific evidences that canolol is a potent antioxidant and anti-mutagenic compound. Galano et al. (2011) reported canolol as similar hydroxyl radical scavenging agent to carotenes, Koski et al. (2003) demonstrated that the lipid peroxyl radical scavenging activity of canolol is higher than that of other compounds isolated from rapeseed oil, while Kuwahara et al. (2004) found canolol to be a good peroxynitrite scavenger.

Iimproved oxidative stability and antioxidant capacity of the mustard and rapeseed oils were also found to correlate well with increased contents of phosphorus and phospholipids (Shrestha et al., 2014). Studies by Bandarra et al. (1999) revealed a high degree of synergy between phospholipids and tocopherols, most likely due to the occurrence of a simultaneous antioxidant mechanism involving Maillard compounds. Antioxidant synergism between tocopherols and other bioactive compounds, such as carotenoids and phenolic compounds, was confirmed by Kamal-Eldin (2006).

\section{CONCLUSIONS}

De-hulling high-oleic rapeseed prior to pressing significantly affected extractability of the bioactive compounds, no such effect was found when the oxidative state of the oil was analyzed. The applied microwave pre-treatment altered the contents of tocopherols, plastochromanol-8, total carotenoids, whereas a remarkable increase in the canolol concentration was noted with longer seed exposition to microwaves. After 9 min of seed MV pre-treatment, a marked increase in the oxidative stability was noted, which was approx. 2-fold higher in relation to the control oils prepared from intact and de-hulled seeds. At the same time, the antioxidant capacity of the oils produced from MV pre-treated seeds for 9 min was nearly 4-fold higher than that of the control HORO and DHORO. With the increase in MV pre-treatment time the formation of hydroperoxides and their degradation products was noticeable. Additionally, prolonged seed heating resulted in unsaturated fatty acid degradation, which was higher in DHOROs than in the HOROs. Although high-oleic rapeseed de-hulling in conjunction with microwaving enabled the production of oil which was high in antioxidant compounds, undesirable changes such as lipid oxidation, darkened color and altered flavor must be monitored to ensure high quality of the oil.

\section{ACKNOWLEDGEMENTS}

The authors would like to thank Dr. Andrzej Anders from University of Warmia and Mazury for the performance of rapeseed mechanical hulling. The authors also thank the Złoto Polskie CLP for providing the high-oleic rapeseed samples.

\section{Conflict of interest statement}

The authors have declared no conflict of interest.

\section{REFERENCES}

Abou-Gharbia HA, Shahidi F, Adel A, Shehata Y, Youssef MM. 1997. Effects of processing on oxidative stability of sesame oil extracted from intact and dehulled seeds. $J$. Am. Oil Chem. Soc. 74, 215-221. http://dx.doi.org/10.1007/ s11746-997-0126-9

Anders A. 2003. Rapeseed coat removal using disks equipped with cylindrical blades. Technical Sci. 6, 65-72.

Anjum F, Anwar F, Jamil A, Iqbal M. 1999. Microwave roasting effects on the physico-chemical composition and oxidative stability of sunflower seed oil. J. Am. Oil Chem. Soc. 83, 777-784. http://dx.doi.org/10.1007/s11746-006-5014-1

AOCS Official Method. 1997. Determination of chlorophyll related pigments in oil (AOCS Method Cc 13d-55).

Azadmard-Damirchi S, Habibi-Nodeh F, Hesari J, Nemati M, Achachlouei BF. 2010. Effect of pretreatment with microwaves on oxidative stability and nutraceuticals content of oil from rapeseed. Food Chem. 121, 1211-1215. http:// dx.doi.org/10.1016/j.foodchem.2010.02.006

Bandarra NM, Campos RM, Batista I, Nunes LM, Empis JM. 1999. Antioxidant synergy of $\alpha$-tocopherol and phospholipids. J. Am. Oil Chem. Soc. 76, 905-913. http://dx.doi. org/10.1007/s11746-999-0105-4

Blekas G, Tsimidou M, Boskou D. 1995. Contribution of $\alpha$-tocopherol to olive oil stability. Food Chem. 52, 289-294. https://doi.org/10.1016/0308-8146(95)92826-6

BSI. 1977. Methods of analysis of fats and fatty oils. Other methods. Determination of carotene in vegetable oils. British Standards Institution, London (BSI 684-2.20).

Cai L, Cao A, Aisikaer G, Ying T. 2013. Influence of kernel roasting on bioactive components and oxidative stability of pine nut oil. Eur. J. Lipid Sci. Technol. 115, 556-563. http://dx.doi.org/10.1002/ejlt.201200337

Cuvelier M-E, Richard H, Berset C. 1992. Comparison of the antioxidative activity of some acid-phenols: structureactivity relationship. Biosci. Biotech. Biochem. 56, 324-325. http://dx.doi.org/10.1271/bbb.56.324 
Durmaz G, Gökmen V. 2010. Determination of 5-hydroxymethyl-2-furfural and 2-furfural in oils as indicators of heat pre-treatment. Food Chem. 123, 912-916. http:// dx.doi.org/10.1016/J.Foodchem.2010.05.001

FAOSTAT (accessed June 2017). Statistics Division. http://faostat.fao.org

Falk J, Munné-Bosch S. 2010. Tocochromanol functions in plants: antioxidation and beyond. J Exp. Bot. 61, 15491566. http://dx.doi.org/10.1093/jxb/erq030

Galano A, Francisco-Márquez M, Alvarez-Idaboy JR. 2011. Canolol: A Promising Chemical Agent against Oxidative Stress. J. Phys. Chem. B. 115, 8590-8596. http://dx.doi. org/10.1021/jp2022105

Gracka A, Jeleń HH, Majcher M, Siger A, Kaczmarek A. 2016. Flavoromics approach in monitoring changes in volatile compounds of virgin rapeseed oil caused by seed roasting. J. Chromatogr. A. 1428, 292-304. http://dx.doi. org/10.1016/j.chroma.2015.10.088

Goffman FD, Thies W, Velasco L. 1999. Chemotaxonomic value of tocopherols in Brassicaceae. Phytochemistry 50, 793-798. https://doi.org/10.1016/S0031-9422(98)00641-4

ISO 1996. Animal and vegetable fats and oils. Determination of peroxide value. International Organization for Standardization, Geneva (ISO 3960).

ISO 2008. Animal and vegetable fats and oils. Determination of anisidine value. International Organization for Standardization, Geneva (ISO 6885).

ISO 2011. Animal and vegetable fats and oils. Determination of ultraviolet absorbance expressed as specific UV extinction. International Organization for Standardization, Geneva (ISO 3656).

Kamal-Eldin A. 2006. Effect of fatty acids and tocopherols on the oxidative stability of vegetable oils. Eur. J. Lipid Sci. Technol. 58, 1051-1061. http://dx.doi.org/10.1002/ ejlt.200600090

Koski A, Pekkarinen S, Hopia A, Wähälä K, Heinonen M. 2003. Processing of rapeseed oil: effects on sinapic acid derivative content and oxidative stability. Eur. Food Res. Technol. 217, 110-114. https://doi.org/10.1007/s00217-003-0721-4

Koski A, Psomiadou E, Tsimidou M, Hopia A, Kefalas P, Wähälä K, et al. 2002. Oxidative stability and minor constituents of virgin olive oil and cold-pressed rapeseed oil. Eur. Food Res. Technol. 214, 294-298. http://dx.doi. org/10.1007/s00217-001-0479-5

Kuwahara H, Kanazawa A, Wakamatu D, Morimura S, Kida K, Akaike T, Maeda H. 2004. Antioxidative and antimutagenic activities of 4-vinyl-2,6-dimethoxyphenol (canolol) isolated from canola oil. J. Agric. Food Chem. 52, 43804387. http://dx.doi.org/10.1021/jf040045+

McDaniel KA, White BL, Dean LL, Sanders TH, Davis JP 2012. Compositional and mechanical properties of peanuts roasted to equivalent colors using different time/temperature combinations. J. Food Sci. 77, C1293-1299. http:// dx.doi.org/10.1111/j.1750-3841.2012.02979.x

Megahed MG. 2001. Microwave roasting of peanuts: effects on oil characteristics and composition. Mol. Nutr. Food Res. 45, 255-257. http://dx.doi.org/10.1002/15213803(20010801) 45:4<255::AID-FOOD255>3.0.CO;2-F

Merrill LI, Pike OA, Ogden LV, Dunn ML. 2008. Oxidative stability of conventional and high-oleic vegetable oils with added antioxidants. J. Am. Oil Chem. Soc. 85, 771-776. http://dx.doi.org/10.1007/s11746-008-1256-4

Moreau RA, Hicks KB, Powell MJ. 1999. Effects of heat pretreatment on the yield and composition of oil extracted from corn fiber. J. Agric. Food Chem. 47, 2867-2871. http:// dx.doi.org/10.1021/jf981186c

Nath UK, Kim H-T, Khatun K, Park J-I, Kang K-K, Nou I-S. 2016. Modification of fatty acid profiles of rapeseed (Brassica napus L.) oil for using as food, industrial feedstock and biodiesel. Plant Breed. Biotech. 4, 123-134. https://doi.org/10.9787/PBB.2016.4.2.123

Przybylski R. 2011. Canola/Rapeseed Oil, in Gunstone FD (Ed.) Vegetable Oils in Food Technology: Composition, Properties and Uses. Blackwell Publishing Ltd. Hoboken, 107-136.

Ręas A, Scibisz I, Siger A, Wroniak M. 2017a. The effect of microwave pre-treatment of seeds on the stability and degradation kinetics of phenolic compounds in rapeseed oil during long-term storage. Food Chem. 222, 43-52. https://doi.org/10.1016/j.foodchem.2016.12.003

Rękas A, Wroniak M, Ścibisz I. 2017b. Microwave radiation and conventional roasting in conjunction with hulling on the oxidative state and physicochemical properties of rapeseed oil. Eur. J. Lipid Sci. Technol. 119, 1600501. https://doi. org/10.1002/ejlt.201600501

Shrestha K, De Me ulenaer B. 2014. Effect of seed roasting on canolol, tocopherol, and phospholipid contents, Maillard type reactions, and oxidative stability of mustard and rapeseed oils. J. Agric. Food Chem. 62, 5412-5419. http:// dx.doi.org/10.1021/jf500549t

Shukla VKS, Wanasandura PKJPD, Shahidi F. 1997. Natural antioxidants from oilseeds, n: Shahidi F (Ed.) Natural Antioxidants: Chemistry, Health Effects, and Applications. AOCS Press, Champaign, Illinois, 97-105.

Siger A, Kachlicki P, Czubiński J, Polcyn D, Dwiecki K, NogalaKałucka M. 2014. Isolation and purification of plastochromanol-8 for HPLC quantitative determinations. Eur. $J$. Lipid Sci. Technol. 116, 413-422. http://dx.doi.org/10.1002/ ejlt.201300297

Siger A, Kaczmarek A, Rudzińska M. 2015. Antioxidant activity and phytochemicals content in cold-pressed rapeseed oil obtained from the roasting seeds. Eur. J. Lipid Sci. Technol. 117, 1225-1237. http://dx.doi.org/10.1002/ejlt.201400378

Tuberoso CIG, Kowalczyk A, Sarritzu E, Cabras P. 2007. Determination of antioxidant compounds and antioxidant activity in commercial oilseeds for food use. Food Chem. 103, 1494-1501. http://dx.doi.org/10.1016/j. foodchem.2006.08.014

Wijesundera C, Ceccato C, Fagan P, Shen Z. 2008. Seed roasting improves the oxidative stability of canola (B. napus) and mustard (B. juncea) seed oils. Eur. J. Lipid Sci. Technol. 110, 360-367. http://dx.doi.org/10.1002/ejlt.200700214

Wroniak M, Anders A, Szterk A, Szymczak R. 2013. Effect of seed dehulling on sensory and physical-chemical quality and nutritional value of cold-pressed rapeseed oil. Food Sci. Technol. Quality. 5, 90-106. https://doi.org/10.15193/ zntj/2013/90/090-106

Vaidya B, Choe E. 2011. Effects of seed roasting on tocopherols, carotenoids, and oxidation in mustard seed oil during heating J. Am. Oil Chem. Soc. 88, 83-90. http://dx.doi. org/10.1007/s11746-010-1656-0

Vujasinovic V, Djilas S, Dimic E, Basic Z, Radocaj O. 2012. The effect of roasting on the chemical composition and oxidative stability of pumpkin oil. Eur. J. Lipid Sci. Technol. 114, 568-574. http://dx.doi.org/10.1002/ejlt.201100158

Yang M, Huang F, Liu Ch, Zheng Ch, Zhou Q, Wang H. 2013. Influence of microwave treatment of rapeseed on minor components content and oxidative stability of oil. Food Bioprocess. Tech. 6, 3206-3216. http://dx.doi.org/10.1007/ s11947-012-0987-2

Yang M, Liu Ch, Huang F, Zheng Ch, Zhou Q. 2011. Effect of dehulling treatment on the oxidative stability of coldpressed low erucic acid rapeseed oil. J. Am. Oil Chem. Soc. 88, 1633-1639. https://doi.org/10.1007/s11746-011-1822-z

Yang M, Zheng Ch, Zhou Q, Liu Ch, Li W, Huang F. 2014. Influence of Microwaves Treatment of Rapeseed on Phenolic Compounds and Canolol Content. J. Agric. Food Chem. 62, 1956-1963. http://dx.doi.org/10.1021/jf4054287

Yoshida H, Takagi S, Mitsuhashi S. 1999. Tocopherol distribution and oxidative stability of oils prepared from the hypocotyls of soybeans roasted in microwave oven. $J . A m$. Oil Chem. Soc. 76, 915-920. http://dx.doi.org/10.1007/ s11746-999-0106-3

Zheng Ch, Yang M, Zhou Q, Liu Ch-S, Huang F-H 2014. Changes in the content of canolol and total phenolic, oxidative stability of rapeseed oil during accelerated storage. Eur. J. Lipid Sci. Technol. 116, 1675-1684. http://dx.doi. org/10.1002/ejlt.201300229

Zhou Q, Yang M, Huang F, Zheng C, Deng Q. 2013. Effect of pretreatment with dehulling and microwaving on the flavor characteristics of cold-pressed rapeseed oil by GC-MSPCA and electronic nose discrimination. J. Food Sci. 78, C961-C970. http://dx.doi.org/10.1111/1750-3841.12161 